\section{Scientific journal}

PHYSICAL AND MATHEMATICAL EDUCATION

Has been issued since 2013.

Науковий журнал

ФІЗИКО-МАТЕМАТИЧНА ОСВІТА

Видається $з 2013$.
ISSN 2413-158X (online)

ISSN 2413-1571 (print)

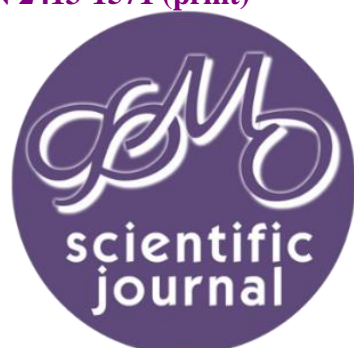

Собченко Т.М. Вибір основних моделей змішаного навчання студентів вищої педагогічної освіти. Фізикоматематична освіта. 2021. Випуск 2(28). С. 17-21.

Sobchenko T. Choice of blended learning models for higher pedagogical education students. Physical and Mathematical Education. 2021. Issue 2(28). P. 17-21.

DOI 10.31110/2413-1571-2021-028-2-003

UDC 371.315.7

T. Sobchenko

H. S. Skovoroda Kharkiv National Pedagogical University, Ukraine sobchenkotetyana79@gmail.com

ORCID: 0000-0002-9213-5556

\title{
CHOICE OF BLENDED LEARNING MODELS FOR HIGHER PEDAGOGICAL EDUCATION STUDENTS
}

\section{ABSTRACT}

Problem formulation. The development of information and computer technologies is quite rapid. The realities of today are that higher education institutions must introduce new and effective teaching methods and technologies that will help to improve the quality of education. The large-scale introduction of online technologies, various models of blended learning is relevant, which leads to fundamental changes in approaches to the organization of education in higher education institutions and in each discipline, especially the role of the audience classes and its effectiveness.

Materials and methods. To address this aim, the following theoretical research methods were used in combination: analysis of pedagogical literature, systematization and generalization of research - to compare different approaches to the implementation of models of blended learning for students of higher pedagogical education.

Results. The analysis of pedagogical literature and the conducted researches allowed to reveal the concept of "blended learning". Based on the existing domestic and foreign works, the existing models of blended learning are considered. The models of blended learning that are expedient to use when studying pedagogical disciplines in the institution of higher pedagogical education are analyzed, in particular "Flipped Model", "Rotation Model", "Lab Rotation Model". The advantages of using blended learning models, inverted learning models - for teachers and students are determined.

Conclusions. The problem of implementing blended learning models is quite relevant and is of interest to many both scholars and practitioners. There is a wide range of models of blended learning, skillful application and combination of which makes the learning process interesting, modern and conscious, and the work of students productive, activates the educational and cognitive activities of higher education, motivates, teaches both independent and teamwork and promotes the development of creative abilities, research skills.

It should be noted that the models "Flipped Model", "Rotation Model", "Lab Rotation Model" and others are tested in technical educational institutions, as well as in the teaching of exact sciences ("Physics", "Mathematics"), while in pedagogical institutions of higher education, especially in the training of future teachers of humanities, this problem requires more in-depth study and, possibly, modification of existing models.

The prospect of further research involves the study, testing and analysis of various models of blended learning for students of higher pedagogical education, including the humanities.

KEY WORDS: blended learning, blended learning models, inverted classroom, rotational model.

\section{INTRODUCTION}

Formulation of the problem. The rapid development of computer technology in today's information society and the spontaneous emergence of a pandemic have led to the widespread use of distance learning technologies in the practice of higher education institutions around the world. Objective factors due to the modernization of the education system are also due to:

- a significant increase in the requirements for the quality of higher education;

- the need to create conditions for the implementation of the concept of lifelong learning; - implementation of tasks of integration of higher education of Ukraine into the European and world educational space;

- democratization of the process of obtaining higher education; - increasing the requirements for the quality of higher education management;

- the need to create additional conditions for the development of the individual trajectory of the applicant;

- introduction of conceptually new tools and concepts into the practical activities of higher education. 
Therefore, the response to these challenges is the large-scale introduction of online technologies, various models of blended learning, which leads to fundamental changes in approaches to the organization of education in higher education and in each discipline, including the role of classroom classes and its effectiveness. Thus, the problem of implementing models of blended learning for higher pedagogical education acquires a new vision, which is to find effective forms, methods and means to solve it.

Analysis of current research. The problem of using blended learning was studied by domestic and foreign scientists, namely its theoretical and methodological aspects: V. Bykova, T. Bodnenko, N. Morze, N. Rashevskaya, S. Semerikov, O. Spirin, E. Smirnova-Tribulska, A. Struck, J. Trius, W. Fandiy, A. Fomina, T. Schroll, K. Bonk, M. Horn, C. Graham, M. Gruber, C. Dziuban, G. Mayer, A. Norberg, K. Sprin, H. Stacker, B. Khan, D. Harrison and others.

A. Kudin, O. Minenko considers the issue of practical implementation of blended learning technologies and offers educational and methodological development - didactic card of the discipline (Kudin, Minenko, 2018). V. Maryanenko explores the place of scientific platforms and cloud services in the system of scientific education of teachers (Maryanenko, 2019). M. Ivashchenko, T. Bykova developed an algorithm for introducing elements of blended learning in the teaching of academic disciplines in higher education institutions by combining the traditional model of learning and innovative model of e-learning (Ivashchenko, Bykova, 2018).

V. Feitosa de Moura, C . their works are devoted to the development of mass open courses as a new form of blended learning in higher education institutions (Feitosa de Moura, Alexandre de Souza, Noronha Viana, 2021).

Ava Clare Marie, O. Robles showed the impact of blended learning on the success of college students, in addition, the paper presents learning strategies for effective integration of the content of disciplines with learning technologies to improve teaching (Ava Clare Marie, Robles, 2012).

D. Bao, J. Jiang, H. Xiao, D. Shen, developed an effective model of online learning, the so-called triangle model (interaction between teacher, student and computer) and its implementation in the educational process to improve effectiveness and support online learning (Bao, Jiang, Xiao, Shen, 2020). N. Khmil analyzes personality-oriented, activity, competence, environmental and informational approaches to the formation of professional readiness of future teachers to use cloud technologies in the educational process (Khmil, 2020).

$\mathrm{O}$. Danysko and S. Semenovska substantiate on the basis of modern approaches to the genesis and modern meaning of the concept of "blended learning" in foreign pedagogical theory, distinguish components (full-time (traditional), distance (individual and collaborative) and electronic (synchronous and asynchronous) learning, determine the levels of practical implementation of blended learning in educational practice (Danysko, Semenovska, 2018) T. Shkil, T. Belikova in their research cite the experience of implementing online methods and interactive digital technologies in higher education institutions in blended learning and reveal its successful results obtained during the preparation of the examination session by students (Shkil, Belikova, 2020).

A. Tomashevska, O.Popova, S.Tkachov, N.Tkachova, O.Grechanyk, V. Grygorash provide effective distance technologies for learning a foreign language in higher education institutions (Tomashevska, (2020).

Theoretical, methodical, practical principles of training future teachers were studied by G. Tkachuk, O. Barna (IT teachers), T. Bondarenko, T. Yevtukhova (primary school teachers), K. Osadcha, V. Osadchy, V. Kruglyk, I. Naumuk (vocational education), I. Malova, M. Moskalyuk, N. Moskalyuk (methodical preparation of the pre-service teacher taking into account modern educational technologies), M. Yachmennyk (preparation of the future teacher of the Ukrainian language and literature).

M. Driscoll identified different approaches to understanding blended learning, namely: as a combination of different modes of organizing learning material; as a combination of different pedagogical concepts; integration of technological means; implementation of current educational objectives through a combination of multimedia and traditional learning technologies (Driscoll, 2001). C. Bonk, C. Graham, B. Michael, M. Horn, T. Bates transformed the essence of the concept of "blended learning" in the pedagogical context and identified models of blended learning.

V. Kukharenko in his works paid his attention to the feasibility of using blended learning in technical institutions of higher education, the specifics of the organization of distance learning for students with special needs in higher education institutions revealed I. Delik, the use of active methods in blended learning researched M. Mokhova, pedagogical and organizational conditions of effective combination of full-time learning and application of distance learning technologies were revealed by Yu. Kapustina. Despite the increased attention of scientists to the problem of implementation of blended learning, the issues of implementation of blended learning models of higher pedagogical education remain insufficiently studied and substantiated. education.

The purpose of the article. Disclosure of features of blended learning's models of applicants for higher pedagogical

\section{RESEARCH METHODS}

To solve this goal, the following theoretical research methods were used in combination: analysis of pedagogical literature, systematization and generalization of research - to compare different approaches to the implementation of models of blended learning for higher pedagogical education.

\section{RESULTS OF RESEARCH AND DISCUSSION}

We consider it expedient to first of all reveal the definition of "blended learning", along with which the terms "e-learning", "hybrid learning", "mobile learning", "distance learning", "flexible learning", "blended learning" are often used, which are not identical.

Blended learning according to A. Litvinov, blended learning is a combination of online and offline learning in one educational process, which forms the "learning experience" of the student and a self-sufficient logical course or subject (Litvinov, 2019). B. Besedin and G. Wagner call blended learning a form in which knowledge is presented for independent study and fulltime together with the teacher. That is, blended learning = classroom learning + technology (Besedin, Wagner, 2017). K. Maxwell 
understands the term "blended learning" as a formal educational program in which a student learns partially online with some element of control over the time, place, route or pace of learning (Maxwell, 2016). According to M. Mokhova, blended learning involves the supply of educational material through independent study of distance learning by students, and the consolidation of material occurs in the mode of meeting with the teacher with the use of active learning methods (Mokhova, 2005). M. Medvedev understands that blended learning is as a system of teaching that combines full-time, distance and self-learning, which includes interaction between teachers, students and interactive sources of information that function in constant interaction with each other, forming a whole (Medvedev, 2015). G. Tkachuk, researching the training of future teachers of computer science in blended learning determines that blended learning is a purposeful process of transfer and assimilation of knowledge, skills, abilities and ways of human cognitive activity, based on a combination of traditional, computer-oriented technologies. distance and mobile-oriented learning. According to the author, blended learning is based on the ideas of constructivism and connectivism, which involve the organization of such activities like: role-playing games, brainstorming and discussions, case method, project method, search methods in printed and electronic sources, written works (essays). At the same time, such forms of work as group, collective, individual, independent are actively used (Tkachuk, 2017). We share the opinion of researcher G. Tkachuk that blended learning is considered effective because it creates conditions for solving the main problem of traditional learning, which is to limit the opportunities for realization and development of potential abilities of students.

The "Recommendations on the introduction of blended learning in institutions of professional higher and higher education" issued by the Ministry of Education and Science state that blended learning is an approach, pedagogical and technological model, methodology that, along with online technologies, also relies on direct interaction between students and teachers. (2020).

Summarizing the different views on blended learning, we can conclude that although it is considered as a form, model, methodology, process, etc., but the common denominator is that it is based on the interaction of subjects in the educational process by combining distance learning (online) and traditional learning (offline). The implementation of blended learning involves the use of a wide range of information and communication technologies, cloud services, educational platforms that are available to all participants in the educational process. This creates optimal conditions for improving information and resource provision for mastering the content of education in the learning process, expanding the range of teaching aids and pedagogical technologies that can be effectively used in the educational process (Bogachkov Yu. Et al., 2012).

Since blended learning has a wide range of learning tools, it provides different models for its implementation. Today in the pedagogical literature there are different models of blended learning from simple and popular to complex and destructive. Therefore, for the effective organization and implementation of blended learning, it is necessary to clearly choose the model that will be effective and meet the demands and expectations of the teacher who will develop the discipline. Therefore, the following should be taken into account when choosing a blended learning model:

- training course (educational and qualification level of applicants);

- the place of the discipline in the curriculum;

- form of organization of training (full-time, part-time, dual);

- number of hours (audience, independent work); - specifics of the faculty (humanitarian, technical);

- purpose, tasks, expected programmed results of the discipline;

- compliance with the content;

- form of control of educational and cognitive activities (oral, written, credit, exam);

- material and technical equipment and support (access to the Internet, equipment, facilities, their number);

- the level of digital competence of teachers and applicants for higher education, the ability to master information and communication technologies;

- the level of student achievement, etc.

Foreign and domestic scientists have proposed a wide range of models of blended learning and described them: "Rotation Model", "Station Rotation Model", "Lab Rotation Model", "Flipped Model". (Model of inverted learning), "Individual Rotation Model", "Flex Model", "Self-Blend Model", "Enriched Virtual Model". V. Kukharenko identifies and analyzes the following models of blended learning: "Rotation model", "Rotation of work zones", "Laboratory of rotation", "Individual rotation", "Intensive residency", "Enriched virtual model", "Autonomous group", "Personal choice".

For pedagogical institutions of higher education, in our opinion, the following models of blended learning should be used, for example, teaching pedagogical disciplines ("Fundamentals of pedagogical skills", "Theory of education", "Didactics", "History of pedagogy", "Comparative pedagogy", "Pedagogy new Ukrainian school "):" Flipped Model "," Rotation Model ", (Lab Rotation Model).

The essence of the "Flipped Model" is that students must master the theoretical material on their own (online). To do this, the teacher either prepares an educational video, or selects ready-made and makes its online content available. There is a wide range of modern services: Edpuzzle, Presentationtube, Movenote, Screencast-oMatic, Zaption, eduCanon, iSpring, SmartPen, Camtasia, Zoom, Meet, Teams and other. Students review, get acquainted, systematize the material. And the teacher must control this process: he gives tests for self-control, uses the forum, asks questions after viewing, offers to write a reference summary, make an intelligence map, and draw a Scribe picture. During the practical and seminar classes, the educational material is consolidated with the use of active learning methods, practical tasks and the organization of productive work of students.

We have identified the following advantages of using the "inverted class" model for students of pedagogical education (Sobchenko, 2021):

- availability of materials at any time;

- independently chosen pace of study;

- flexibility and convenience;

- saving material costs;

- building an individual educational trajectory; 
- the possibility of disclosing the potential of the applicant;

- independent control and responsibility for their own activities;

- increasing the motivation and stimulation of educational and cognitive activities by selecting the content of educational material and the form of its presentation;

- raising the level of digital literacy;

- formation of key competencies;

- creating conditions for further development and lifelong learning.

For teachers, the benefits are:

- change of role and position in accordance with the Concept "New Ukrainian School";

- bridging the digital divide between participants in the educational process;

- increase of network and information literacy;

- new opportunities for interaction;

- expression of creativity and creativity;

- the possibility of organizing group projects, creative tasks, gamification;

- creating preconditions for further professional development.

We also consider the implementation of the "Rotation Model" in the study of pedagogical disciplines to be effective and optimal. It involves a combination of traditional offline learning using a variety of activities and self-directed online learning individually at a pace and time. There is an organization of educational activities within the whole group, project group, small group or individual work of each student under the guidance of the teacher. G. Tkachuk proposes to implement the rotational model not in "pure" form, but in combination with other models. Thus, according to the place and schedule of training, the rotational model contains four submodels: the model of changing stations, the model of changing laboratories, the model of inverted training, the personalized model (Tkachuk G., 2017). The effectiveness of this model will directly depend on the extent to which the teacher will be able to organize the work of students, namely: - choose the appropriate topic; - to single out microgroups in the academic group; - think to study the topic of different activities (for different groups); - determining the content of activities; - arrangement of the audience space; - ensuring the work of study groups in full. The peculiarity of this model is that regardless of the type of activity, the task set by the teacher, all groups must work together and work closely with each other and perform appropriate tasks depending on personal needs and level of training of each. We also consider it appropriate to use the "Lab Rotation Model", as it provides a constant schedule of classes in classrooms and equipped laboratories, including computer classrooms. First, students work under the guidance of a teacher in a regular classroom, then they move on to a computer class, where they work individually, consolidating their knowledge in practice.

\section{CONCLUSIONS AND PROSPECTS FOR FURTHER RESEARCH}

Thus, the problem of implementing blended learning models is quite relevant and of interest to many both scientists and practitioners domestic and foreign. There is a wide range of models of blended learning, skillful application and combination of which makes the learning process interesting, modern and conscious, and productive work, activates the educational and cognitive activities of higher education, motivates, teaches both independent and teamwork, promotes development of creative abilities, research skills. And this, in turn, will help expand the range of learning opportunities and the implementation of active forms and methods of learning. The prospect of further research involves the study and implementation, testing and analysis of various models of blended learning for students of higher pedagogical education, studying the possibilities of cloud services and technologies for the implementation of blended learning for future teachers.

It should be noted that the models "Flipped Model", "Rotation Model", "Lab Rotation Model" and others are tested in technical educational institutions, as well as in the teaching of exact sciences ("Physics", "Mathematics"), while in pedagogical institutions of higher education, especially in the training of future teachers of humanities, this problem requires more in-depth study and, possibly, modification of existing models.

The prospect of further research involves the study, testing and analysis of various models of blended learning for students of higher pedagogical education, including the humanities.

\section{Список використаних джерел}

1. Литвинов А.С. Педагогічний провайдинг інновацій в освіті: навч. посіб. /за заг.ред. В.В.Борисова. Суми, 2019. С. 134.

2. Беседін Б., Вагнер Г. Навчальні технології XXI століття: «змішане навчання»: зб.наук.пр. Гуманізація навчальновиховного процесу. №5 (85), 2017. С. 208-217.

3. Clifford Maxwell What Blended Learning Is - and Isn't URL: https://www.blendedlearning.org/what-blended-learning-is-andisnt/

4. Рекомендації щодо впровадження змішаного навчання у закладах фахової передвищої та вищої освіти URL: https://mon.gov.ua/storage/app/media/vishcha-osvita/2020/zmyshene\%20navchanny/zmishanenavchanniabookletspreads-2.pdf

5. Мохова М.Н. Активные методы в смешанном обучении в системе дополнительного педагогического образования (автореф. дис...канд. пед. наук). Москва.

6. Медведева М.С. Формирование готовности будущих учителей к работе в условиях смешанного обучения (автореф. дис...канд. пед. наук). Нижний Новгород.

7. Ткачук Г. В. Змішане навчання та особливості використання ротаційної моделі у навчальному процесі. Інформаційні технології в освіті. 2017. № 4 (33). С. 143-156.

8. Богачков Ю., Биков В., Пінчук О., Манако А. Організація середовища дистанційного навчання в середніх загальноосвітніх навчальних закладах: посібник. Київ. Педагогічна думка, 2012. С.19.

9. Теорія та практика змішаного навчання: монографія / В.М.Кухаренко та ін. Харків, 2016. 284 с. 
10. Собченко Т. М. Використання технології “перевернутий клас" як моделі змішаного навчання. Стан освітнього процесу в умовах викликів сьогодення : матеріали Міжнародної науково-практичної конференції (Дніпро, 12 лютого 2021 р). Дніпро: Міжнародний гуманітарний дослідницький центр, 2021. С. 76-77.

\section{References}

1. Litvinov A.S. Pedahohichnyi provaidynh innovatsii v osviti [Pedagogical provision of innovations in education]: textbook. way. / for ed. V.V. Borisova. Sumy, 2019. P. 134 [in Ukrainian].

2. Besedin B., Wagner G. Navchalni tekhnolohii XXI stolittia: «zmishane navchannia» [Educational technologies of the XXI century: "blended learning"]: textbook Humanization of the educational process. №5 (85), 2017. pp. $208-217$ [in Ukrainian].

3. Clifford Maxwell What Blended Learning Is - and Isn't URL: https://www.blendedlearning.org/what-blended-learning-is-andisnt/ [in English].

4. Rekomendatsii shchodo vprovadzhennia zmishanoho navchannia u zakladakh fakhovoi peredvyshchoi ta vyshchoi osvity [Recommendations for the introduction of blended learning in institutions of professional higher and higher education] URL: https://mon.gov.ua/ua/osvita/visha-osvita/rekomendacij-shodo-vprovadzhennya-zmishanogo-navchannya-u-zakladahfahovoyi-peredvishoyi-ta-vishoyi-osviti [in Ukrainian].

5. Mokhova M.N. Aktivnye metody $v$ smeshannom obuchenii $v$ sisteme dopolnitel 'nogo pedagogicheskogo obrazovaniya [Active methods in blended learning in the system of additional pedagogical education] (author's ref. Candidate of Pedagogical Sciences). Moscow [in Russia].

6. Medvedeva M.S. Formirovanie gotovnosti budushhikh uchitelej k rabote v usloviyakh smeshannogo obucheniya [Formation of the readiness of future teachers to work in blended learning conditions] (author's ref. Candidate of Pedagogical Sciences). Nizhny Novgorod [in Russia].

7. Tkachuk G.V. Zmishane navchannia ta osoblyvosti vykorystannia rotatsiinoi modeli u navchalnomu protsesi [Blended learning and features of using the rotational model in the learning process]. Information technology in education. 2017. № 4 (33). P. 143-156 [in Ukrainian].

8. Bogachkov Y., Bykov V., Pinchuk O., Manako A. Orhanizatsiia seredovyshcha dystantsiinoho navchannia $v$ serednikh zahalnoosvitnikh navchalnykh zakladakh [Organization of distance learning environment in secondary schools]: a guide. Kiev. Pedagogical thought, 2012. P. 19 [in Ukrainian].

9. Teori ya ta praktika zmi shanogo navchannya [Theory and practice of blended learning]: a monograph / V.M. Kukharenko and others. Kharkiv, 2016. 284 p. [in Ukrainian].

10. Sobchenko T.M. Vykorystannia tekhnolohii "perevernutyi klas" yak modeli zmishanoho navchannia [The use of technology "inverted classroom" as a model of blended learning]. The state of the educational process in the face of today's challenges: materials of the International scientific-practical conference (Dnipro, February 12, 2021). Dnipro, 2021. P. $76-77$ [in Ukrainian].

\section{ВИБІР ОСНОВНИХ МОДЕЛЕЙ ЗМІШАНОГО НАВЧАННЯ СТУДЕНТІВ ВИЩОЇ ПЕДАГОГІЧНОЇ ОСВІТИ}

\section{T.М. Собченко}

Харківський національний педагогічний університет імені Г.С.Сковороди, Україна

Анотація. Формулювання проблеми. Розвиток інформаційних та комп'ютерних технологій відбувається досить стрімко. Реалії сьогодення такі, що заклади вищої освіти мають упроваджувати нові та ефективні методики і технології навчання, які будуть сприяти підвищенню якості освіти. Актуальним є широкомасштабне впровадження онлайн-технологій, різноманітних моделей змішаного навчання, що веде за собою грунтовні зміни у підходах до організації навчання у закладах вищої освіти та в кожній дисципліні, зокрема ролі аудиторних занять та ефективності його проведення.

матеріали і методи. Для вирішення поставленої мети було застосовано в комплексі такі теоретичні методи дослідження: аналіз педагогічної літератури, систематизація та узагальнення досліджень учених - для зіставлення різних підходів щодо реалізації моделей змішаного навчання студентів вищої педагогічної освіти.

Результати. Аналіз педагогічної літератури та проведених досліджень дозволив розкрити поняття «змішане навчання». На основ наявних вітчизняних та зарубіжнх праць розглянуто існуючі моделі змішаного навчання. Проаналізовано моделі змішаного навчання, які доцільно використовувати під час вивчення педагогічних дисциплін у закладі вищої педагогічної освіти, а саме «Flipped Model» (Модель перевернутого навчання), «Rotation Model» (Pomaчійна модель), «Lab Rotation Model» (Модель зміни лабораторій). Визначено переваги використання моделей змішаного навчання, моделі перевернутого навчання для викладачів та для студентів.

Висновки. Проблема впровадження моделей змішаного навчання є досить актуальною та цікавить багатьох як науковців так і практиків. Існує досить широкий спектр моделей змішаного навчання, вміле застосування та поєднання яких, робить навчальний процес цікавим, сучасним та свідомим, а роботу студентів продуктивною, активізує навчально-пізнавальну діяльність здобувачів вищої освіти, мотивує, привчає як до самостійної так і до роботи в команді, сприяє розвитку творчих здібностей, дослідницьких умінь. А це, в свою чергу, сприятиме розширенню діапазону можливостей навчання та реалізації активних форм та методів навчання.

Слід зазначити, що моделі «Flipped Model» (Модель перевернутого навчання), "Rotation Model» (Pomaчійна модель), "Lab Rotation Model» (Модель зміни лабораторій) та інші є апробованими у технічних закладах освіти, а також у викладанні точних наук ("Фізика», “Математика») тоді, як у педагогічних закладах вищої освіти, особливо у підготовці майбутніх педагогів гуманітарних спеціальностей ия проблема вимагає більш глибокого вивчення та, можливо, модифікації існуючих моделей. Тому перспективою подальшого дослідження є вивчення, апробування та аналіз різних моделей змішаного навчання студентів закладів вищої педагогічної освіти, зокрема гуманітарних спеціальностей.

Ключові слова: змішане навчання, моделі змішаного навчання, перевернутий клас, ротаційна модель.

\section{$(\mathrm{CC})$ BY-NC-SA}

This work is licensed under Creative Commons Attribution-NonCommercial-ShareAlike 4.0 International License. 